\title{
The retreat of the delta: a geomorphological history of the Po river basin during the twentieth century
}

\author{
Giacomo Parrinello ${ }^{1}$ Simone Bizzi ${ }^{2} \cdot$ Nicola Surian ${ }^{2}$
}

Received: 29 April 2020 / Accepted: 8 April 2021 / Published online: 21 June 2021

(c) The Author(s) 2021

\begin{abstract}
The morphology of rivers and deltas, like many features of the Earth's physical geography, is today subject to dramatic and rapid changes due to human actions. Deprived of sediment from their basins and besieged by rising sea levels, many deltas are at risk of complete disappearance. Despite a rich historical scholarship on rivers, we know little about the history of these important geomorphological processes. This paper sheds light on the geomorphological history of rivers by investigating the case of the Po River basin and its delta during the twentieth century. By combining the insights of fluvial geomorphology and a historical methodology, the paper analyses three main drivers of geomorphic alterations in the catchment that had an impact on the delta: hydroelectricity, sand and gravel mining, and methane extraction. In each case, it focuses on how experts, policy-makers, and overseers understood and regulated (or not) these geomorphic alterations. During much of the twentieth century, engineers and hydrologists monitored geomorphic processes with increasing detail, while state and business actors practiced multiple forms of sediment management. For most of the twentieth century, however, experts did not acknowledge the scale and nature of human-induced geomorphic alteration. Sediment management, moreover, did not take into account sediment scarcity until late in the century, and remained exclusively motivated by local concerns. Through this particular case, this paper offers insights on the historical limits to environmental expertise and policy when facing long term and largescale geomorphic processes, and encourages a more sustained incorporation of fluvial geomorphology into the history of water systems.
\end{abstract}

Keywords Delta - Sediment · fluvial geomorphology · Po River · environmental expertise · environmental policy $\cdot$ Anthropocene

Simone Bizzi

simone.bizzi@unipd.it

Giacomo Parrinello

giacomo.parrinello@sciencespo.fr

Nicola Surian

nicola.surian@unipd.it

1 Center for History at Sciences Po (CHSP), Paris, France

2 Department of Geosciences, University of Padua, Padua, Italy 


\section{Introduction}

After centuries in which they grew farther out into the sea-a process called progradation-in the second half of the twentieth century many deltas of the world started to sink and retreat. This historic reversal is part of a large-scale alteration of sediment fluxes, which is transforming the morphology and ecology of river systems around the world (Bravard 2018). The alteration of sediment fluxes is also one of the most conspicuous signs of human impact on natural processes and is often evoked in relation to the Anthropocene, the debated new epoch of the Earth's geological history characterized by human geophysical agency at a planetary scale (Crutzen and Stoermer 2000; Crutzen 2002; Steffen et al. 2007, 2011; on sediment see Syvitski and Kettner 2011; Cooper et al. 2018). Sediment flux alteration and delta retreat put the lives of millions of people at risk in places like the Mekong, the Yangtze, or the Mississippi deltas, especially when combined with localized subsidence and the effects of climate change-induced sea-level rise (Kondolf et al. 2018). This paper investigates the history of one such case: the Po River delta in Italy during the twentieth century. The paper analyses geomorphic alterations at the watershed scale that had an impact on the delta, focusing on how historical actors understood and regulated (or not) these alterations. It shows that river experts and regulators, while aware of human influence on geomorphic processes at the catchment scale, failed until the late twentieth century to take into account the possibility of sediment scarcity and the anthropogenic retreat of the Po delta.

Present-day fluvial geomorphology has produced a sophisticated understanding of the links between upstream basins and deltas and their anthropogenic alteration, including the impact of dams on sediment fluxes, the consequences of sand and gravel mining, and the construction of embankments (Kondolf and Piégay 2011). This literature has shown how modifications in upstream portions of a watershed can have significant consequences on downstream sediment deposition, influencing the morphology of the river channel as well as delta build-up or retreat (Wohl et al. 2017; Wohl 2017). While fluvial geomorphology has been sensitive to the consequence of human intervention, its focus remains the understanding of geomorphological processes themselves rather than their social and historical drivers. During the past few years, interdisciplinary social sciences and political ecology have begun integrating geomorphic processes into our understanding of water systems and society (see for instance Micheaux et al. 2018; Carse and Lewis 2017; Cortesi 2018). Scholars have argued that sediments are essential components of more-than-human watery assemblages; their presence (or absence), their composition, and movement shape and are shaped by social inequalities and uneven power relations. While these contributions offer important conceptual and methodological tools to analyze the social and political dimensions of geomorphic processes, they say little about how these dimensions have evolved over time. Geomorphic alterations play out on at large spatial scales and over the long term, with significant spatial and temporal lags between causes and effects (Kondolf and Podolak 2014). Historians can offer a unique contribution to understand the way human societies have influenced these processes.

Surprisingly, environmental and water historians have thus far paid scant attention to the geomorphic dimension of river histories. They have mostly studied river development, bringing into focus its massive ecological consequences, from the large-scale alteration of the hydrology of the American West (Worster 1985) to the massive pollution of the Rhine River during two centuries of river development (Cioc 2002). Historians of the Columbia (White 1995) and the Rhône rivers (Pritchard 2011) maintained that hydrological and 
ecological transformations should not be viewed as departures from a natural state but as new hybrid configurations of nature and technology. These contributions offer indispensable insights on the deep nexus that exists between the ecological transformation of rivers and the historical processes of economic growth, technological innovation, the making of scientific knowledge, and institutional policy-making. These works, however, invariably show a strong water bias in their understanding of river systems, remaining almost entirely focused on hydrological and ecological processes. Innovative research on the Viennese Danube (Hohensinner et al. 2013; Winiwarter et al. 2013) and, more recently, on the Bengal Delta (Bhattacharyya 2018) has shown that there is much to be gained in our understanding of key historical processes - from colonialism to urbanization-by viewing rivers and deltas as geomorphic systems.

The study of the Po River basin and its delta we present in this paper contributes to bringing the environmental history of fluvial geomorphological dynamics into sharper focus. The Po delta is located in the Adriatic Sea and is the terminal of a basin that covers most of northern Italy. During the Early Modern period, the Po Delta considerably advanced into the sea, due in part to the extensive deforestation of its basin as well as to the sedimentary consequences of the Little Ice Age (Stefani 2017). In the second half of the twentieth century, however, the Po delta started to retreat (Syvitski and Kettner 2007). The process slowed down only at the end of the century when, according to a recent study, retreat might have stopped altogether and reversed again (Ninfo et al. 2018). The retreat of the delta during the twentieth century is perhaps the most dramatic example of morphological changes in the Po River basin linked to the alteration of sediment fluxes that have impacted other parts of the river basin as well (Surian and Rinaldi 2003, 2008; Rinaldi et al. 2010). Like most river historiography, the literature on the environmental history of the Po River has mainly focused on ecological and hydrological aspects (Coates 2013; Parrinello 2017, 2018). This literature has mostly ignored the associated geomorphological processes. This paper aims to shed light on how twentieth-century historical actors understood and regulated the geomorphological implications of river development and resource extraction in the Po watershed, and especially the impact on the Po delta.

This paper focuses on the processes that have contributed the most to the geomorphological transformation of the Po delta: hydropower production, sand and gravel mining from the riverbeds for the construction industry, and extraction of methane gas within the delta. The Po watershed is the largest river basin in Italy and the richest in water. Unsurprisingly, it has also been the core of hydropower development of the country, resulting in the construction of sediment-trapping dams across almost all of its tributaries and subtributaries. Moreover, during the second half of the twentieth century, firms linked to the construction industry extensively mined the Po River and its tributaries for sand and gravel. This activity has had a significant impact on sediment fluxes basin-wide and has contributed to a decreasing amount of sediment reaching the delta. Unlike hydropower, mining has also caused localized channel incision and embankment erosion that has, in turn, generated some policy response. During the middle of the twentieth century, natural gas producers extracted methane from the subsoil of the Po Delta. While this activity did not alter sediment fluxes, it generated accelerated and worrisome subsidence of the delta, suggesting the possibility of anthropogenic delta retreat.

Hydropower production, mining, and methane extraction did not all contribute to the alteration of the delta in the same way, nor did they generate the same kind of concerns. In each case, we will analyze how experts and regulators understood and tried to manage the geomorphological dimension and impact of these practices. We will then compare the knowledge and regulation of the geomorphic consequences of these three drivers. Based 
on this comparison, we argue that temporal and spatial lags between causes and effects in watershed-scale geomorphic processes contribute to explain the failure of river experts and regulators in considering sediment scarcity. This, in turn, offers insights on the challenges of environmental policy when confronted with long-term geophysical processes.

\section{Hydroelectricity}

The Po River basin is the largest in Italy, with a drainage area of $70,091 \mathrm{~km}^{2}$ and a mean annual discharge of approximately $1500 \mathrm{~m}^{3} \mathrm{~s}^{-1}$. The river flows from the Western Alps to the Adriatic Sea, for a total length of $651 \mathrm{~km}$. It drains most of northern Italy's Alpine rivers, including the Ticino and the Adda, and the subalpine lakes Maggiore, Como, and Garda, as well as glacier-fed sub-tributaries and small lakes. It also drains a large share of the northern Apennines, from the Tanaro River basin near Alessandria to the Secchia River basin near Modena. The Po River, thus, is the collector of a vast and complex hydrological network that spans most of northern Italy and its mountain ranges (fig. 1).

This catchment has been a hotspot of hydropower production for centuries. At the peak of mechanical hydropower use, during the second half of the nineteenth century, at least 12,000 agricultural, artisanal, and industrial watermills were active along the Po River network. The shift to hydroelectricity made this water system even more central in the energy regime of rapidly-industrializing northern Italy. The first commercial hydroelectric plant was built in 1895 along the Adda River. It was soon followed by others along the Ticino River and other Alpine tributaries. While the growth of the sector remained moderate at the beginning of the century, during and after World War I hydroelectricity boomed, driven by industrial demand and new, favorable legislation. Between 1915 and 1927, 186 new

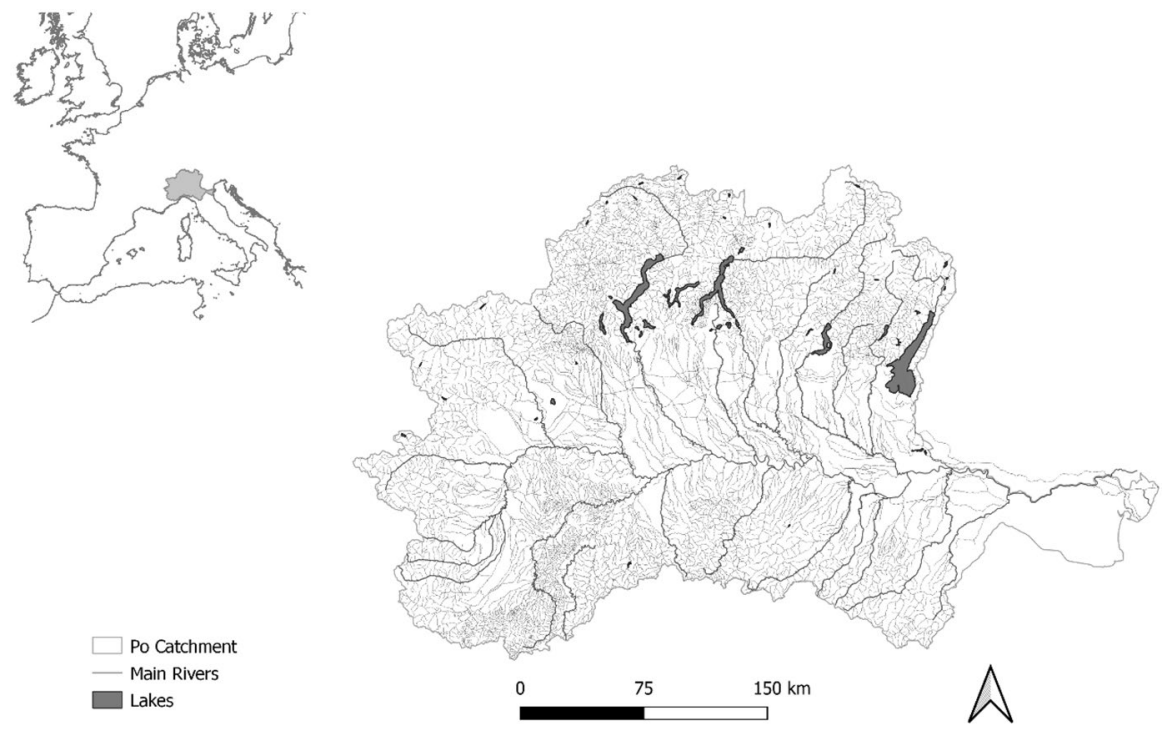

Fig. 1 The Po River catchment. Cartography by the authors 
plants were added to the 112 built before 1915. This development continued unabated until World War II and reached a peak in the 1960s (Parrinello 2018, pp. 669-673).

With the growth of this sector, producers increasingly felt the need to regulate hydrological and climatic variability to control energy production. The first hydroelectric plants had been built along the banks of large rivers. Edison's plant at Paderno d'Adda, for instance, exploited the rapids of the Adda River via a simple diversion. Most hydropower plants that followed in the footsteps of this pioneering infrastructure similarly exploited rapids of the Alpine tributaries of the Po via diversions of the river flow through penstocks. These were the most easily accessible and profitable locations for hydropower and did not demand complicated hydrological manipulations. Nevertheless, using simple diversions of river flows to power hydroelectric plants presented a major disadvantage: the dependence on the vagaries of a river's hydrological regimes. Lake-fed rivers such as the Adda and the Ticino afforded a large and relatively reliable discharge year-round, and it was not by chance that the first two power plants were located along their banks. Glacier-fed rivers, however, were less reliable, especially over winter. An unreliable water supply presented a significant economic risk: hydropower plants demand large investments which, to become profitable, require the production and distribution of energy without interruptions. (Parrinello 2018, pp. 663-664).

Reservoirs were the solution to this problem. Reservoirs could store water during periods of abundance and allow producers to use it in times of scarcity, thus regulating river flows independently from climatic and meteorological conditions. In the aftermath of World War I, reservoirs received growing attention by hydroelectric producers and engineers (see for instance Forti 1921). An exceptional drought that began in 1921 and ended in 1922 accelerated this debate, revealing to producers and policy-makers the hydrological vulnerability of the hydroelectric energy regime. Writing immediately after the drought, state engineer Giulio de Marchi maintained that the consequences of the drought in northern Italy had lowered the annual production of the hydropower plant "as if no machines had functioned at all for two consecutive months" (Marchi 1922). At the time of the drought, early hydropower companies had built a few hydroelectric reservoirs, mostly in the Alpine tributaries. In the years following the drought, however, the number of hydroelectric reservoirs rose massively and continued to grow up to the late 1950s (fig. 2). By the late 1950s, 142 dams altered the flow of almost every tributary and sub-tributary of the Po River (Commissione ANIDEL per lo studio dei problemi inerenti alle dighe 1951).

Reservoirs, however, do not store just water. They also trap coarse sediments and part of the fine sediments transported by the river. When a basin is heavily impounded, this can reduce the amount of sediment flowing downstream with notable effects on geomorphic processes. In some cases, the amount of sediment impounded is so great as to alter the morphology of the river channel, causing incision. In the worst cases, it can harm delta build-up, by reducing the overall amount of sediment that make land accretion possible (Petts and Gurnell 2005). This is the case in the Po River basin, where river morphology and dynamics have been altered (e.g. widespread channel narrowing and incision in the main tributaries and the Po River over the last 50 to 60 years) and where the delta has undergone remarkable degradation since the 1950s (Marchetti 2002; Surian and Rinaldi 2003; Rinaldi et al. 2010). While it is not possible to quantify directly how much of this alteration was due to the impact of hydroelectric impoundment, especially concerning the delta, this development certainly had a major influence (Surian et al. 2009).

Hydropower engineers and developers in the Po basin were well aware that they were trapping sediments as well as water. For them, this was a major issue: trapped sediment reduces the efficiency of dams, considerably limiting the volume of water they can hold. 

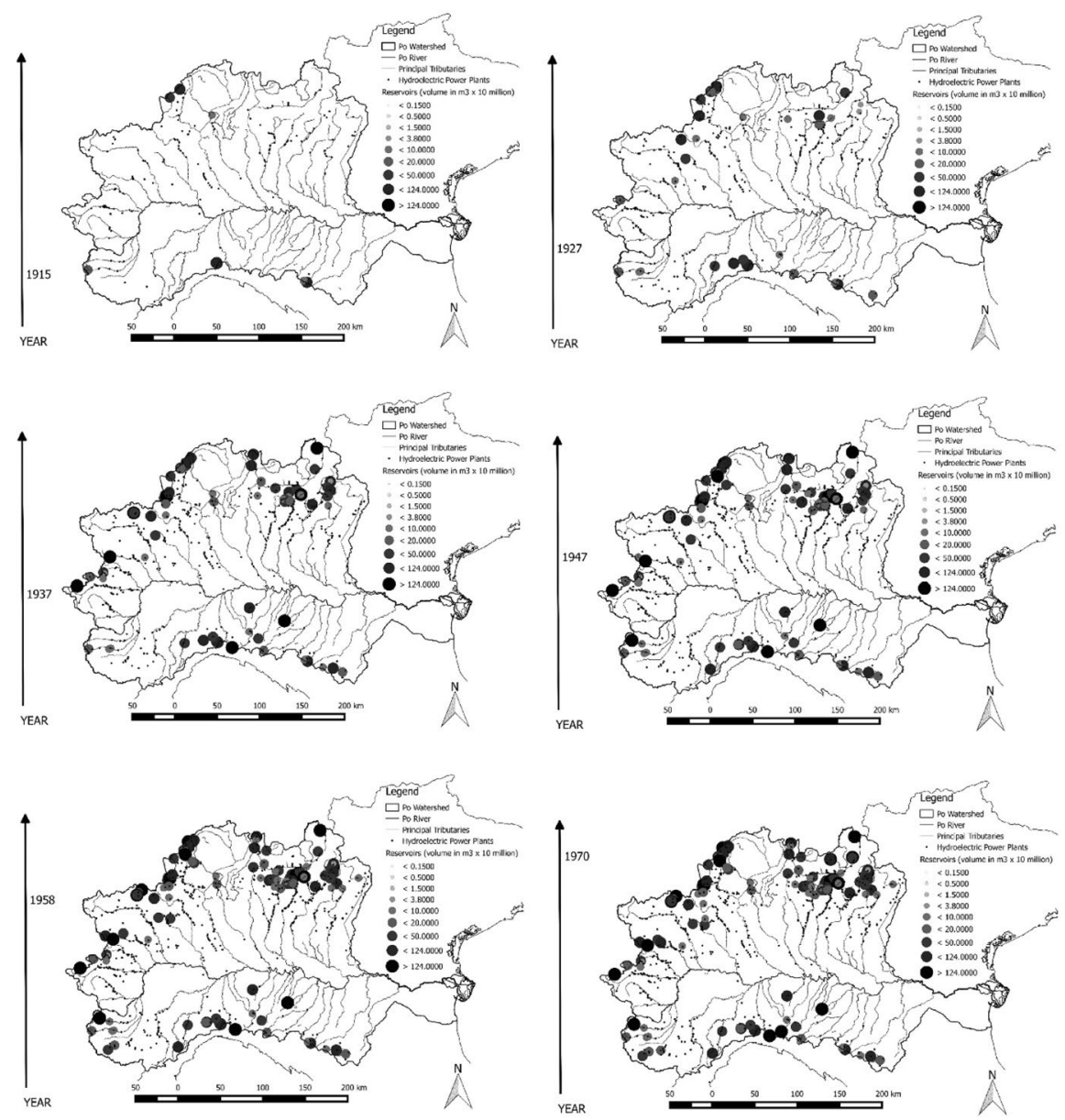

Fig. 2 Hydroelectric power plants (small black dots) and reservoirs (large graduated circles) in the Po River basin between 1915 and 1970. Cartography by the authors

This, in turn, endangers the conspicuous capital investment that went into reservoir construction. Both state and hydroelectric company engineers started debating the issue in the early 1920s, at the onset of hydroelectric reservoir development. In a paper on reservoirs published in 1920 as part of the official journal of the Italian Ministry of Public Works, engineer Angelo Forti discussed what he called the "insidia solida", or "solid menace" (Forti 1920). Forti explained sediment transport in rivers, distinguishing between suspended load and bed load. Referring to the case of two reservoirs built at the turn of the century, Forti argued that sediment caused the reservoirs' siltation and the formation of deltas upstream. This was a major issue, given their strategic role for regulation of hydroelectric energy production. Following up on Forti's paper, in 1921, engineer Piero Bonetti reminded his readers that even irrigation reservoirs silted up and were therefore regularly emptied and cleaned. The seasonality of irrigation made possible the emptying and cleaning of these reservoirs without major economic disruptions. This was much more complicated with hydroelectric reservoirs, which were coupled with costly machinery and 
production plants. Hydropower companies and investors wanted to maximize the return on the investment and thus considered any discontinuity in production as a potential loss (Bonetti 1921).

The availability of experimental data on sediment transport in rivers contributed significantly to these debates. In 1912, as part of the activities of a national commission for the development of inland navigation, the Italian Ministry of Public Works established an experimental Po River Hydrographic Bureau. This agency was devoted to collecting hydrological data at the scale of the entire basin. Through constant monitoring and data collection at hundreds of networked stations, the bureau ultimately aimed to produce a better understanding of the Po basin as an interconnected hydrological system. While initially established temporarily, the bureau became a permanent branch of the Italian Ministry of Public Works after World War I, when it was incorporated into a newly established national hydrographic service (Parrinello 2017). The Po River Hydrographic Bureau began collecting data on suspended load in 1913, a year after its creation. Engineer Mario Giandotti, head of the bureau, argued that "knowing with the closest approximation the amount of matter eroded from the earth's surface and carried by water" was an essential to "the study of meandering rivers, of delta progradation, of hydraulic filling, of dredging" and, ultimately, to the understanding of the Po hydrological system itself (Giandotti 1913, pp. 117-118). Whereas the data systematically collected by the bureau concerned only suspended sediment, in a 1922 publication Giandotti also attempted to estimate the bed load of all the Apennines tributaries of the Po (Giandotti 1929b). Reservoir sedimentation drove subsequent research of the hydrographic bureau on sediment transport and, in 1939, the new head of the bureau, engineer Mario Visentini, authored a comprehensive inventory of sediment deposition in reservoirs in Elettrotecnica, a leading journal of the hydroelectric industry (Visentini 1939).

While studying sediment transport and warning about the danger of reservoirs sedimentation, hydrologists and engineers also discussed sediment management strategies. The 1939 inventory by Visentini, for instance, included the systematic discussion of the technical means through which operators managed these sediments, from periodic clean-ups to flushing - the sudden release of the admixture of water and sediment by opening the dam. Mostly, however, these actors identified reforestation or afforestation as the most effective management strategy. Forest coverage, they argued, dramatically reduced soil erosion and the amount of sediment that ended up in rivers and, in turn, reservoirs. Promoting reforestation or afforestation of reservoirs' headwaters would therefore solve-or at least curbsedimentation (see for instance Giandotti 1922).

This was not a novel argument. Starting from the late nineteenth century, a similar argument underpinned state initiatives for mountain afforestation and flood control, known under the name of bonifica montana (mountain reclamation). The impetuous development of hydroelectric power and the menace of reservoir sedimentation, however, added a new sense of urgency to the matter, provided a new and decisive argument in favor of state intervention into reforestation, and generated support for this policy among hydroelectric producers. Boosted by fascism with new legislation in the 1930s, "bonifica montana" would guide state action for sediment management in the basin headwaters for much of the twentieth century (Gaspari and Barberis 1994; Armiero 2011, pp. 32-43; Malfitano 2011; Agnoletti 2018, pp. 200-229). If sediment load was an illness that could cripple energy production, state-sponsored reforestation and sediment control was seen as the cure. Mountain reclamation (implying reforestation but also torrent-control works) continued across the watershed after World War II causing a remarkable decrease of sedimentation (see for instance the interventions in Piedmont's sub-basins charted in ASTo, Genio Civile, 2823). 
By the same token, it likely impacted sediment transport in the Po River (Surian et al. 2009; Grabowski et al. 2014) and caused a decrease of sedimentation in the delta.

While focusing on strategies to reduce sediment availability, state and hydroelectric company engineers showed a complete disregard of the possible large-scale consequences of sediment-altering infrastructure. Nowhere is this more evident than in the case of the power plant of Isola Serafini. First envisioned in 1948, this power plant was built at the turn of the 1960s by S.I.M.A (Società Idroelettrica Medio Adige), a partnership between Edison, Adriatica and Centrale, three of the most important players of the sector. The only power plant exploiting the current of the Po River itself, this power plant was located in a meander of the river, taking advantage of the presence of a river island from which it took its name (Isola Serafini). The main feature of this power plant from a morphological perspective was the construction of a dam across the main channel of the Po River. This dam cut the river channel in two, creating a major discontinuity between the upper and the lower sections of the river, with consequences on ecological connectivity and sediment flux (Bizzi et al. 2015).

When planning the dam, the engineers of the cooperating companies did pay attention to sediment. Notably, they included solid transport among the key points they wanted to be studied through a fluvial model they commissioned to the University of Padua (Marzolo and Istituto di Idraulica dell'Universita' di Padova 1957). Like their predecessors, however, they were mostly concerned with dam sedimentation and the impact of sediment on turbines. At some point, engineers even considered the possibility that sedimentation of the dam during a flood might cause an avulsion event. When the main channel obstructed by sediment accumulated behind the dam, the river would spill over the embankments and carve for itself a new channel, with catastrophic consequences on neighboring farmland and populous urban centers (Sottocomitato tecnico 1957). They quickly dismissed this risk as unlikely and the solution they envisioned to sedimentation did not go beyond regular flushing. Regular flushing, then, was the only provision that the authorities imposed on the company when approving the project (Genio Civile di Piacenza and De Cristoforo 1960). The potential downstream consequences of this major interruption of sediment fluxes, including the likely impact on delta sedimentation, do not appear to have been taken into consideration by either engineers or public officers, mirroring the general disregard of the impact of hydroelectricity on sediment transport in the Po watershed.

\section{Sand and gravel mining}

A similar pattern of disregard toward possible negative consequences of altering sediment transport by both experts and overseers has characterized the history of sand and gravel mining for much of the twentieth century. However, whereas the only form of sediment management in the hydroelectric sector was aimed at reducing sediment availability (mountain reclamation), the intensification of sediment mining over the second half of the twentieth century led to the first, substantial interventions to counter sediment scarcity.

Mining of sediments from the river has a long history. Along with the seashore, rivers are the most important source of sand and gravel, which are extracted from riverbeds as well as from banks and alluvial plains. These materials are essential to the modern construction industry (Beiser 2018). In the mid-nineteenth century, river gravel was used in combination with mortar-instead of stone-for the construction of embankments, bridges, and also (especially in certain regions of the Po watershed) private constructions 
(Cavalieri Sau-Bertolo 1853, p. 45). The use of sediment from rivers increased with the diffusion of concrete from the mid-nineteenth century onward (Marzo Magno and Iori 2012). By then, civil engineering works such as bridges, railroads, and other infrastructure regularly employed cement, usually mixed with sand and gravel in varying proportions. The key player of the cement and concrete sector in Italy, the Societa' Bergamasca dei Cementi, which would later evolve into the multinational corporation Italcementi, began operating in the Po Valley in the 1860s, with its first plants being located along the valleys of the Brembo and Serio rivers-two northern tributaries of the Po (Fumagalli 1964).

Until the 1940s, sand and gravel to meet this growing demand were largely mined by hand, using traditional instruments such as the badilon, a colander attached to a three-meter long pole that filtered out water and retained gravel (Bergonzi and Migliavacca 2012). These techniques had a limited extraction capacity. The features and impact of aggregate mining, however, changed dramatically after World War II thanks to the availability of cheap diesel excavators and the booming construction industry. Advances in earthmoving machinery, including the substitution of steam engines with internal combustion engines and the introduction of hydraulic cylinders, rendered excavators more efficient, cheaper, and easier to use. This, in turn, led to their massive diffusion in Europe during the postWorld War II decades (Haycraft 2011, p. 722). Furthermore, demographic and urban growth, as well as the collateral boom of the construction industry in post-war Italy, created an unprecedented surge in the demand for aggregate material (Mocarelli 2010).

Hydrologists acknowledged the impact of mining in the tributaries on sediment transport to the Po River since the late 1920s, but discounted the potential large-scale consequences. In a study from 1929, the aforementioned director of the hydrographic bureau, Mario Giandotti, attempted to calculate sediment transport in the Apennine's tributaries of the Po, as well as their contribution to sediment load of the Po River. These calculations showed a significant discrepancy between the high quantity of sediment these tributaries carried in the upper portions of their basin and the very low amount of sediment that reached the Po River downstream. According to Giandotti, the only reasonable explanation for this discrepancy was the impact of an "external factor" that, in his opinion, could only be "the continuous, ceaseless extraction of gravel materials, for road maintenance, for construction, and for the needs of railroads" (Giandotti 1929, p. 6). Based on available data, Giandotti estimated that sand and gravel extracted from the river for the sole needs of road construction (that is, excluding railroad and other construction works) amounted to an average of more 500,000 cubic meters per year (Giandotti 1929, p. 6). Giandotti, however, was not concerned about possible negative consequences of this "ceaseless extraction" because he did not observe any changes in the local flood regime. There was no need to worry about mining.

This relaxed attitude likely played a role in the regulation of sediment mining. The extraction of sand and gravel from most rivers was regulated via a public licence regime: the state, owner of most rivers of the country, authorized extraction of river sediment in exchange for a fee. This rule, however, did not apply to those areas where aggregate mining was customary "since time immemorial" (that is, since before the creation of the Italian state). Legislation passed at the turn of the twentieth century explicitly subordinated the emission of licences to the safety of riverfront inhabitants and entrusted state engineers with oversight and issuing of licences (1904). State engineers, however, could prevent extraction only if it caused an explicit and evident menace to the security of riverfront inhabitants or activities. In many cases, mining operations did not need any authorization at all since they were happening since time immemorial. Even when they did need authorization, the state distributed licences generously. Following mainstream hydrological 
arguments, the Magistrato per il Po-a special institution created in the 1950s to manage public works pertaining to the Po River basin—encouraged extraction with the explicit aim of lowering the riverbed and benefit flood protection (Magistrato per il Po 1984, p. 119).

Records in the state and local archives reveal numerous infractions to this already quite liberal regulation. These cases also reveal how much extractive practices had changed from the time of manual extraction before World War II. In 1964, the forest police found a man, Roberto B., near Cogne, who was extracting sand from the bed of the Valnontey River with a mechanical excavator. He was doing it illegally on behalf of a small construction enterprise of which he was an employee. According to the police, he had been doing it for several days, extracting 200 cubic meters of gravel. Interestingly, nothing happened in the end: the administration did not seem interested in pursuing this infraction (Servizi Forestali della Regione Autonoma Valle d'Aosta 1964). Similar small-scale illegal or irregular mining operations linked to the construction industry were discovered by the forest police and by fishermen associations in Piedmont. In 1967, Ezio A. was caught extracting sand and gravel from the Stura di Lanzo River. Once again, the man was alone, equipped with a mechanical excavator and a truck, and had managed to extract 120 cubic meters of sand and gravel on behalf of his employer, Vittorio B., owner of a construction firm specialized in road construction. Even in this case, the administration did not pursue the infraction: as the forest police report noted, the extraction "did not compromise the good hydraulic regime of the water course" (Corpo Forestale dello Stato 1967).

The combination of booming demand for aggregate, powerful new extraction technology, and a liberal licence regime contributed to a massive increase in extraction capacity and increased the rate of aggregate extraction way above the annual sediment yield of the basin. The annual sediment yield at the beginning of the twenty-first century is 5 to 6 million cubic meters, and bed load can be assessed at about 10 percent of the total sediment yield (i.e. about 0.5 to 0.6 million cubic meters). Since sediment extraction impacts the bed load (gravel and sand), the extracted volumes were more than ten times the annual bed load and, maybe, up to a hundred times more during the peak of mining activity (e.g. during the late 1970s). According to one calculation, the extraction of aggregate from the main channel of the Po River between the confluence of the Ticino and the beginning of the delta rose from 2 million cubic meters in 1920 to more than 4 million cubic meters in 1974, which became 7 million cubic meters in 1979 (Lamberti et al. 1990, pp. 195-196). These data, however, should not be trusted blindly. The authors gathered data from official extraction licenses, and corrected them to account for presumed irregularities in reporting. According to the authors, however, even with corrections these data are more likely to be underestimates than overestimates. The amount of aggregate extracted from the entire watershed in 1980 amounted to no less than 60 million cubic meters (Dal Cin and Simeoni 1990, p. 335).

At the turn of the 1970s, the geomorphological consequences of this massive extraction were becoming evident. The impressive surge in sand and gravel mining (fig. 3) had significantly lowered the riverbeds of most tributaries of the Po and undermined embankments and bridges. Whenever a particularly intense flood event occurred, some of the most badly undermined bridges collapsed and killed people. In 1973, a bridge on the Stura River (a tributary of the Po) crumbled during a flood, killing five people. In the lawsuit that followed that episode, seventeen individuals were accused of manslaughter. Among them were five engineers of the Genio Civile, blamed for lack of oversight on sand and gravel mining upstream (Bisio 1978). In another example, the aftermath of a 1977 flood of the Toce River (another tributary of the Po) led several mayors of the valley to blame 


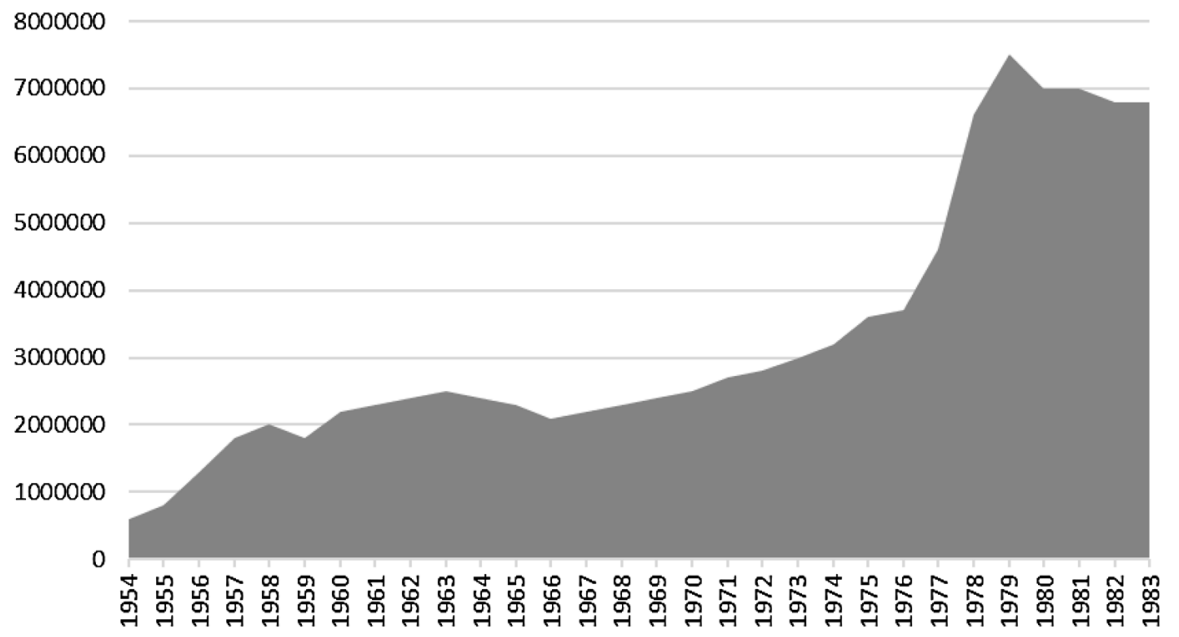

Fig. 3 Estimate of sediment extracted from the main channel of the Po River between Pavia and the delta in m3/year. Chart by the authors with data from Lamberti et al. 1990, pp.195-196

the uncontrolled extraction of sand and gravel from the riverbed for multiple embankment failures and bridge collapses (1977a, b).

The mounting evidence of the geomorphic impact of sand and gravel mining caused a change in sediment mining regulation. At the turn of the 1980s, the Magistrato per il Po dramatically reversed his mining licence policy and began a vigorous attempt at curbing extraction of aggregate. A new regulation issued in 1980 announced a reduction in licences by 50 percent of the amount of aggregate extracted in 1979, followed in 1982 by an additional reduction of 30 percent. The ongoing crisis of the construction industry of the early 1980s helped the Magistrato per il Po to stymie opposition to restrictive regulations. In 1983, the Magistrato per il Po consolidated the new policy and affirmed the need to subordinate extraction licences to flood security and river management (Magistrato per il Po 1984, pp. 122-124). This new and stricter regulation represented a major discontinuity, as it was the first time that the authorities sought to address the issue of sediment scarcity, not excess. It is important to note, however, that it was enforced only to safeguard the security of flood containment infrastructure on the Po tributaries, and was not motivated by concerns about catchment-scale processes or impact on the delta. The scale of regulatory concerns, moreover, remained local.

\section{Methane extraction}

Scientific and policy concerns about the Po delta emerged for the first time in the 1960s, because of a different extractive process: the extraction of methane gas from the sedimentary deposits of the delta. For centuries, scholars of rivers had believed that the delta was steadily prograding. The extraction of methane gas provoked the accelerated subsidence of the delta and made clear, for the very first time, that human intervention could radically reverse its geomorphological configuration and endanger the existence of the delta itself. 
By the mid-twentieth century, when methane gas extraction started, the Po Delta had already experienced moderate subsidence. From the second half of the nineteenth century, the introduction of steam-powered drainage pumps had allowed landowners to lift water from lower to upper ground, and hence to drain large expanses of low-lying wetlands. Drainage of the delta accelerated with the introduction of diesel- and electricity-powered drainage pumps. This led to the almost complete reclamation of the delta by the 1940s. Ad hoc drainage canals emptied into the Adriatic Sea, while monumental embankments and sea dikes protected the drained lands from the flow of the Po River and of the neighboring Adige River, as well as from the water of the Adriatic Sea. Mechanical drainage causes the soil of the former wetlands to subside, by stopping the accumulation of peat soil and causing a reduction in the volume of the remaining peat (Galloway et al. 2016). According to calculations of the $1950 \mathrm{~s}$, the soil of the Po River delta had subsided of some $0.5 \mathrm{~cm}$ per year during the first half of the twentieth century (Morandini 1958, p. 65).

In spite of drainage-induced subsidence, up until the mid-twentieth century, no one doubted that overall the delta was continuously prograding. In 1940, Marco Visentini published a comprehensive and lengthy synthesis of fifteen years of data collecting and research conducted by the Po River Hydrographic Bureau he directed. The 1940 study touched upon multiple aspects of the delta's hydrology and geomorphology, including a sketch of the delta's morphological history, sediment transport, discharge, tidal currents and saltwater intrusion. In his report, Visentini briefly mentioned the "great sedimentation power of the Po", the existence of "strict quantitative linkages" between sediment transport in the watershed and delta sedimentation, and provided an estimate of the annual sediment yield of the Po River, which he assessed as averaging 15.5 million cubic meters (Visentini 1940, pp. 69, 159). According to Visentini, the overall trajectory of the delta amounted to:

a continuous increase, which amounts, in the period of 125 years taken into account, to the formation of 8204 hectares of new land above the sea, and in the increase of 2630 million of cubic meters of the volume of the beach, including the submerged portion (Visentini 1940, p. 170).

When Visentini published this lengthy study, extraction of methane from the delta's substrate had just started. In a few decades, this extraction set in motion a major geomorphological transformation that would dramatically contradict Visentini's vision of a steadily prograding delta.

Methane extraction caused problems from the outset. Experimental extraction of methaniferous water in the delta began in the mid-1930s, in the context of economic autarchy policy of the late fascist regime and further stimulated at the eve of World War II. The hostilities affected extraction only marginally. After the war, extraction increased quickly, stimulated by specific funding provisions of the European Recovery Plan. In 1949, methane extracted from the delta amounted to 40 percent of the entire production of Italy. Methane in the Po delta lies in a uniform Quaternary strata, evenly distributed below the entire delta, where gas is dissolved in fresh and saltwater-an admixture called methaniferous water (Elmi 2001). To obtain the gas, one needs to pump out methaniferous water. Only after it is brought to the surface can methane gas be separated from water. A multiplicity of small-scale enterprises, organized into an association, controlled and operated the extraction wells. Their combined impact was extremely significant: between 1938 and 1960, they opened more than 4000 wells spread out across the whole surface of the Po delta. From the outset, methane extraction generated bitter conflicts between farmers of the delta and methane producers. After separating methane from water, methane producers expelled water through existing drainage canals. As soon as production began in earnest, farmers 
complained that water rejected by methane producers was salty and it contaminated the fields close to canals. Moreover, the drainage of water by-products placed an extra burden on an already saturated drainage system (Tchaprassian 2002, pp. 341-342). At the turn of the 1950s, however, the escalation of extraction caused a much worse and intractable issue: accelerated land subsidence.

In 1947, one engineer pointed out the risk of accelerated subsidence: "[...] extracting a conspicuous volume of water, which is undoubtedly of fossil origin, could cause the constipation of porous strata and hence possible subsidence of the ground level [...]" (Attilio Scicli quoted in Tchaprassian 2002, p. 347). Counter-expertise by the association of methane gas producers quickly dismissed his claim. However, in the aftermath of a flood in 1951, it appeared that subsidence was happening after all, and quite fast. The 1951 flood of the Po River was the highest ever recorded, and caused substantial damage to drainage infrastructures such as pumps, embankments and drainage canals (Ministero dei Lavori Pubblici and Servizio Idrografico Centrale 1952). To prepare the reconstruction of such infrastructure, one of the major reclamation consortia of the delta region demanded a series of large-scale measurement and leveling campaigns. After the first campaign in 1952, engineer Silvero who directed the consortium repeated the measurements in 1954. To his great surprise, he noted an "inexplicable and significant" lowering of the level of the entire drainage infrastructure of the delta compared to just two years prior (Silvero quoted in Tchaprassian 2002, p. 346). This troubling discovery was confirmed by multiple investigations afterwards: a measurement campaign by the Istituto Geografico Militare recorded a subsidence of up to $74 \mathrm{~cm}$ between 1951 and 1956 (Tchaprassian 2002, p. 346). In 1958, renowned physical geographer Giuseppe Morandini claimed that during the first 50 years of the century the rate of subsidence had not surpassed $1.5 \mathrm{~cm}$ per year, but from the early 1950s onward it increased up to $25 \mathrm{~cm}$ per year, with overall subsidence of more than $2 \mathrm{~m}$ since 1951 (Morandini 1958, p. 65).

By the time Morandini published his assessment, subsidence had become much-contested political terrain. Initially confined to debates between engineers and technical agencies, accelerated subsidence became a public issue when the delta flooded again in 1957. Unlike in the past, in 1957 the delta flooded exclusively because of subsidence: embankments and drainage pumps had lowered so much that they were not functional anymore. Subsidence-induced flooding happened again in 1958 and in 1960, raising concerns among the local population and the authorities. In the wake of the floods, the local population pointed to methane extraction as the cause. Industrialists' experts, however, contested the existence of any clear causal link between methaniferous water extraction and delta subsidence (Tchaprassian 2002, p. 348). In 1957, the matter had been handed over to an official commission, which advised for a suspension of extraction. It took yet another subsidenceinduced flood to lead the government to enact a first, experimental suspension. By then, the population was fully convinced that methane extraction was responsible for subsidence and flooding and clamored for a suspension of extraction. In 1960, the head of the police and the prefect (local representative of the executive branch) alerted the central authorities of the need to respond to the concerns of the population, lest to fuel "the propaganda of extremist parties" (D’Onofrio Questore di Rovigo 1960; Pandozy Prefetto di Rovigo 1960).

In 1961, the state enforced a temporary ban on a selected area of the delta. The effects of the extraction ban were almost immediately visible in the area and, two years later, the state enforced a permanent extraction ban on the entire delta. It would be wrong, however, to conclude that the ban was a triumph of environmental awareness: the subsidence crisis was putting the delta's agriculture out of business through repeated flooding, and had generated a political crisis at the local level that most certainly contributed towards the 
authorities enacting the proposed ban. By the time of the ban, the delta's methane deposits were no longer profitable, therefore weakening the position of methane producers. This is a common occurrence in environmental regulation, as shown by histories of pollution (see for instance Stradling and Stradling 2008; Mosley 2014). Regardless of the political and economic factors that explain it, the ban was a turning point in the subsidence crisis. After the ban, subsidence slowed down to $6 \mathrm{~mm} /$ year (very close to those before the 1950s), whereas it was around $150 \mathrm{~mm} /$ year during the period of methane extraction (e.g. in the period 1956-1961) (Elmi 2001).

While this intervention stopped accelerated subsidence, it did not stop the retreat of the delta. The subsidence crisis spurred a wave of studies to monitor the delta's geomorphology. As they confirmed the positive impact of the ban, these studies continued to register an alarming rate of erosion of the coastline. Given that methane extraction was no longer a factor, scholars turned to other explanations and in particular to sediment mining. In a study of the river basin hydrology published in 1981, Lino Cati, director of the Po River Hydrographic Bureau at the time, discussed the rise in sediment extraction during the 1970s. Cati remarked that extraction of aggregate was equal to the entire yearly sediment budget, but he was cautious in his assessment of the retreat of the delta. Moreover, he did not establish any explicit link between extraction upstream and the delta (Cati 1981, p. 284). Since the mid-1970s, however, other authors did not shy away from linking observed erosion and the massive, ill-regulated extraction of aggregate from the river basin (Bondesan and Cin 1975; Dal Cin 1983; Marabini 1985).

Despite mounting scientific evidence, authorities did not introduce any regulation of sediment-altering processes aimed at protecting the delta. Unlike the subsidence crisis that, by the 1950s, was observable with the naked eye, the physical changes of the delta that scientists decried in the 1980s were only visible through careful instrumental measurements and satellite imagery. Furthermore, while they could convincingly argue that these processes depended upon catchment-scale processes, it was-and remains to this day-difficult to assess precisely and on a quantitative basis the weight of different factors. Finally, unlike the subsidence-induced flooding of the late 1950s, or collapsing bridges in the Po tributaries over the 1970s, the erosive phenomena these authors observed had no immediate consequences on the land and its people. There was no political crisis to spur radical regulatory action.

\section{Expertise, regulation, and their limits}

By comparing the three drivers analyzed in the preceding sections, we can gain some broader insights on expertise and regulation of geomorphic impacts in the Po River system over the twentieth century. Scientific awareness of large-scale geomorphic processes existed for quite a long time. While this awareness remained theoretical until the turn of the twentieth century, starting in 1913, the Po River Hydrographic Bureau began a program of systematic measurement of suspended load at the scale of the whole catchment. Ten years later, the bureau started a program of measurement of bed load. In 1929, these experimental measurements allowed the then- bureau director Mario Giandotti to formulate quantitative estimates of the contribution of Apennine tributaries to the overall Po River sediment load, identifying the early effects of sediment mining for the construction industry. In 1940, thanks to measurements by the Po River Hydrographic Bureau, its director at the time, Marco Visentini, published a likely accurate quantification of the river's total 
sediment transport to the delta. While this knowledge was insufficient to map precisely sediment fluxes at the scale of the watershed, it is important to acknowledge these early efforts, which disprove any simplistic view of past ignorance as opposed to present-day awareness.

Despite awareness of large-scale geomorphic processes, and of possible human interferences, river experts were not focused on issues of sediment scarcity and the retreat of the Po delta. Engineers of the hydroelectric sector were mostly concerned about excess of sediment in relation to the functionality of reservoirs. They did not consider the possibility of sediment scarcity. Hydrologists of water agencies identified advanced signs of anthropogenic alterations, such as Giandotti did in 1929. However, they did not consider these threats until the middle of the century. The possibility of anthropogenic sinking of the delta was taken into account only with the accelerated subsidence crisis of the 1950s, and even then, it was not connected to changes occurring at the catchment scale. Only at the end of the twentieth century did river scientists and geomorphologists start to argue that river development and extractive practices at the watershed scale were causing the delta to shrink, by reducing the amount of sediment that reached the seashore.

Policy and regulation lagged even farther behind. Sediment management strategies were introduced as a response to localized emergencies, not to tackle large-scale geomorphic processes, and answered to sometimes opposing rationales. With reforestation and other soil control measures, hydropower producers and state agencies sought to manage sediment, but only in order to maintain efficiency of reservoirs. Their purpose, moreover, was (and is) to reduce sediment availability, since it is detrimental to the operation of reservoirs. Hydropower actors never considered catchment-scale consequences or possible impact on the delta of reducing sediment fluxes to the lower basin, not even when building the Isola Serafini power plant that cut in two the main course of the Po River. The regulation of mining introduced in the early 1980s was a response to the immediate dangers of collapsing bridges and failing embankments in many tributaries of the Po, not to the longer-term effects of mining in the delta. Unlike with hydropower, this regulation was intended to increase the amount of sediment flowing downstream, but it was ostensibly not motivated by concerns with the delta.

Only at the turn of the twenty-first century, have public institutions started discussing sediment management at the catchment scale to counter sediment scarcity. In 2004, the four administrative regions within the Po watershed signed an agreement on sediment management at the basin scale. In 2006, following that agreement, the Po River Basin Authority (AdBPo), approved the first sediment management plan (Autorità di bacino del fiume Po 2006), aiming at facilitating sediment connectivity between the catchment and the delta. The Po watershed authority has been created in 1989, thus ten years before the EU Water Framework Directive that introduced the basin district as spatial unit for river management. This authority is responsible for river basin planning but has little enforcement power. While the 2006 sediment management plan is an important sign of discontinuity, it is not clear whether it will be sufficient to produce real change. To be sure, even if the retreat might have stopped, as claimed by Ninfo et al. (2018), the Po River basin remains a system subject to heavy geomorphological disturbances. 


\section{Conclusion}

The retreat of a delta is the result of human-geomorphological interactions occurring over the long term and at multiple spatial scales. Due to the significant time and spatial lag between causes and effects (Kondolf and Podolak 2014), understanding the present-day retreat of a delta requires taking into account the long history of human interaction with the geomorphology of river systems. We have shown that the historical processes responsible for the retreat of the Po Delta covered much of the twentieth century and occurred both at the scale of delta itself and at the scale of the entire Po River basin. These processes demonstrate the deep linkages between industry and the river's geomorphology. We have also shown both the existence of, and the limits to the scientific understanding and to effective regulation of geomorphic processes. While aware of catchment scale geomorphic processes, river experts acknowledged in full the geomorphological consequences of economic activities in the river basin only at the end of the twentieth century. Regulation, on the other hand, did not move past the local scale or beyond the level of emergency response before the turn of the twentieth century.

The temporal and spatial lag between causes and effects contributes to explaining both the failure to take into consideration the full scope of anthropogenic influences and the absence of concerns for the basin and the delta in the regulation of sediment-related extractive practices. Only when geomorphic alterations resulting from human activities were visible and quantifiable, would scientists and experts confidently claim for the existence of causal links. Likewise, only when geomorphic impacts of human activities were immediately visible would institutional actors discuss approaches for sediment management. Temporal and spatial proximity made impact more visible and causal links explicit, creating political controversies that, in turn, pushed institutional actors to introduce regulations. Distance in space and time between causes and effects, on the contrary, made it hard to make strong scientific claims and politically inexpedient to introduce effective regulation. These are issues to account for in rethinking river sediment policy today.

The slowness of expertise and the failure of policy to take into account human influence on geomorphic processes offers insights that go beyond this case study. On the one hand, it shows the limits of modern environmental expertise when facing complex natural processes that are difficult to quantify or for which it is hard to establish direct causal links. It also reveals the historical limits of environmental policy in regulating large-scale processes that span multiple generations. This has broader implications. Temporal lags of several decades - when not centuries - and spatial lags that sometimes cross multiple continents, govern many other geological processes of planet Earth, from the nitrogen to the carbon cycles. Human actions have altered these cycles up to the point of ushering in a new geological epoch. While past humans have been often conscious of their environmental influence, proof of the scale of such influence has emerged slowly and effective regulation is not in sight. Understanding the limits of expertise and the failures of policy in dealing with such scales in the past can help finding new and hopefully better way to deal with our fraught present and uncertain future.

Acknowledgements The authors presented a preliminary version of this paper at the 2019 ESEH conference in Tallinn, Estonia. We wish to thank the other presenters and attendees for their questions and comments. We also thank Dr. Santiago Gorostiza for his insightful comments on an early draft. Research leading to this article has received funding from the People Programme (Marie Curie Action) of the European Union's Seventh Framework Programme (FP7/2007-2013) under REA grant agreement No. 327403. The authors gratefully acknowledges the funding support of an Emergence(s) Grant of the City of Paris, Bureau 
of Innovation, to the project "Shifting Shores: An Environmental History of Morphological Changes in Mediterranean River Deltas in the Twentieth Century", of which this paper is an output.

Funding Open access funding provided by Università degli Studi di Padova within the CRUI-CARE Agreement.

Open Access This article is licensed under a Creative Commons Attribution 4.0 International License, which permits use, sharing, adaptation, distribution and reproduction in any medium or format, as long as you give appropriate credit to the original author(s) and the source, provide a link to the Creative Commons licence, and indicate if changes were made. The images or other third party material in this article are included in the article's Creative Commons licence, unless indicated otherwise in a credit line to the material. If material is not included in the article's Creative Commons licence and your intended use is not permitted by statutory regulation or exceeds the permitted use, you will need to obtain permission directly from the copyright holder. To view a copy of this licence, visit http://creativecommons.org/licenses/by/4.0/.

\section{References}

Agnoletti M (2018) Storia del bosco: il paesaggio forestale italiano. Laterza, Roma-Bari

Armiero M (2011) A rugged nation: mountains and the making of modern Italy. White Horse Press, Cambridge UK

Autorità di bacino del fiume Po (2006) Delibera N. 20-2006-5/4/2006 Adozione di "Programma generale di gestione dei sedimenti alluvionali dell'alveo del fiume Po-Stralcio confluenza Tanaro, confluenza Arda". In: Autorità Bacino Distrettuale Fiume Po. https://adbpo.gov.it/archiviodelibere/delib era-n-20-2006-del-5-4-2006-adozione-di-programma-generale-di-gestione-dei-sedimenti-alluv ionali-dellalveo-del-fiume-po-stralcio-confluenza-tanaro-confluenza-arda/. Accessed 16 Apr 2020

Beiser V (2018) The world in a grain: the story of sand and how it transformed civilization. Riverhead Books, New York

Bergonzi E, Migliavacca R (2012) Gh**iaiaroli e navaroli di Po e Ticino. Racconti autobiografici di Erminio Bergonzi e RomanoMigliavacca. In: Mestieri del Po, Navaroli, Renaioli, Contadini, Lavandaie, Effegie. Cremona, pp 209-217

Bhattacharyya D (2018) Empire and ecology in the Bengal delta the making of Calcutta. Cambridge University Press, Cambridge

Bisio G (1978) Diciassette a giudizio per il crollo del ponte che uccise cinque persone. La Stampa 4

Bizzi S, Dinh Q, Bernardi D et al (2015) On the control of riverbed incision induced by run-of-river power plant. Water Resour Res 51:5023-5040. https://doi.org/10.1002/2014WR016237

Bondesan M, Dal Cin R (1975) Rapporti tra erosioni lungo i litorali emiliano-romagnoli e del delta del Po e attività estrattiva negli alvei fluviali. In: Italia Nostra, Consiglio Regionale, Regione Emilia Romagna,Dipartimento Servizi del Territorio (eds) Cave e assetto del Territorio. pp 126-131

Bonetti P (1921) L'insidia solida e la sistemazione montana nei riguardi dei laghi artificiali. Il G Genio Civ $150-157$

Bravard J-P (2018) Crises sédimentaires du globe 2: Deltas, une crise environnementale majeure. ISTE Group

Carse A, Lewis JA (2017) Toward a political ecology of infrastructure standards: or, how to think about ships, waterways, sediment, and communities together. Environ Plan Econ Space 49:9-28. https:// doi.org/10.1177/0308518X16663015

Cati L (1981) Idrografia e idrologia del Po. Istituto Poligrafico e Zecca dello Stato, Roma

Cavalieri Sau-Bertolo N (1853) Istituzioni di architettura statica e idraulica, vol 2. Stabilimento tipografico-calcografico-librario degli editori fratelli Negretti, Mantova

Cioc M (2002) The Rhine: an eco-biography, 1815-2000. University of Washington Press, Seattle

Coates PA (2013) A story of six rivers: history, culture and ecology. Reaktion Books, London

Commissione ANIDEL per lo studio dei problemi inerenti alle dighe (1951) Le dighe di ritenuta degli impianti idroelettrici italiani 7 vv. Associazione Nazionale Imprese Distributrici di Energia Elettrica, Milano

Cooper AH, Brown TJ, Price SJ et al (2018) Humans are the most significant global geomorphological driving force of the 21st century. Anthr Rev 5:222-229. https://doi.org/10.1177/2053019618 800234

Corpo Forestale dello Stato (1967) Processo verbale di contravvenzione al R.D. 25/7/1904, art. 97 lettera m 
Cortesi L (2018) The muddy semiotics of mud. J Polit Ecol 25:617-637. https://doi.org/10.2458/v25i1. 22945

Crutzen PJ (2002) Geology of mankind. Nature 415:23-23. https://doi.org/10.1038/415023a

Crutzen PJ, Stoermer EF (2000) The "Anthropocene." IGBP Newsl 41:17-18

Dal Cin R (1983) I litorali del delta del Po e alle foci dell'Adige e del Brenta: caratteri tessiturali e dispersione dei sedimenti, cause dell'arretramento e previsioni sull'evoluzione futura. Boll Della Soc Geol Ital 102:9-56

Dal Cin R, Simeoni U (1990) Appendice B: Caratteri granulometrici delle sabbie cavate nel basso corso del Po. In: Tacconi P, Consorzio per il Canale Emiliano-Romagnolo (eds) Po: acquAgricolturAmbiente, Vol. 2. L'alveo e il delta, Il Mulino, Bologna

de Marchi G (1922) La produzione di energia elettrica in Italia nell' anno 1921 e le ripercussioni della siccita' dell'autunno 1921 e dell'inverno 1921-1922. L'Elettrotecnica

de Micheaux FL, Mukherjee J, Kull CA (2018) When hydrosociality encounters sediments: transformed lives and livelihoods in the lower basin of the Ganges River. Environ Plan E Nat Space 1:641-663. https://doi.org/10.1177/2514848618813768

D'Onofrio Questore di Rovigo A (1960) Situazione politica determinata dall'alluvione nel Basso Polesine

Elmi C (2001) Aspetti geomorfologici di carattere ambientale. In: Note illustrative della Carta Geomorfologica della Pianura Padana. pp 149-164

Forti A (1920) I laghi serbatoi artificiali e l'insidia solida. Ann Consiglio Super Delle Acque 3-16

Forti A (1921) Importanza dei serbatoi e dei laghi artificiali nella produzione e distribuzione dell'energia elettrica. Il G Genio Civ 77-87

Fumagalli C (1964) La Italcementi: origini e vicende storiche: per il centenario della Societa, 18641964. Italcementi, Bergamo

Galloway DL, Erkens G, Kuniansky EL, Rowland JC (2016) Preface: Land subsidence processes. Hydrogeol J 24:547-550. https://doi.org/10.1007/s10040-016-1386-y

Gaspari O, Barberis C (1994) Il segretariato per la montagna, 1919-1965: Ruini, Serpieri e Sturzo per la bonifica d'alta quota. Presidenza del Consiglio dei Ministri, Dipartimento per l'informazione e l'editoria, Roma

Genio Civile di Piacenza, De Cristoforo G (1960) Schema di disciplinare contenente gli obblighi e le condizioni cui dovra' essere vincolata la concessione della derivazione d'acqua dal fiume Po in localita' "isola Serafini" in Comune di Monticelli d'Ongina, chiesta dalla Soc. Ing. T.Bormida con le domande 10.1 e 15.3.1928 e domanda di variante 18.4.1948 della subingredita ditta "A.Terzi" con Societa" Idroelettrica Medio Adige

Giandotti M (1913) Seconda relazione del direttore dell'ufficio idrografico del Po

Giandotti M (1929) Contributo allo studio del trascinamento dei materiali nell'alveo dei torrenti Stab. Tipolit. del Genio civile, Roma

Giandotti M (1922) Influenza dei boschi e delle sistemazioni montane sul regime degli afflussi. L'Elettrotecnica 9:261-265

Grabowski RC, Surian N, Gurnell AM (2014) Characterizing geomorphological change to support sustainable river restoration and management. WIREs Water 1:483-512. https://doi.org/10.1002/wat2.1037

Haycraft W (2011) History of construction equipment. J Constr Eng Manag 137:720-723

Hohensinner S, Sonnlechner C, Schmid M, Winiwarter V (2013) Two steps back, one step forward: reconstructing the dynamic Danube riverscape under human influence in Vienna. Water Hist 5:121-143. https://doi.org/10.1007/s12685-013-0076-0

Kondolf GM, Piégay H (2011) Geomorphology and Society. In: The SAGE Handbook of Geomorphology. SAGE Publications Ltd, London, pp 105-118

Kondolf GM, Podolak K (2014) Space and time scales in human-landscape systems. Environ Manage 53:76-87

Kondolf GM, Schmitt RJP, Carling P et al (2018) Changing sediment budget of the Mekong: cumulative threats and management strategies for a large river basin. Sci Total Environ 625:114-134. https://doi. org/10.1016/j.scitotenv.2017.11.361

Lamberti A, Montefusco L, Paris E (1990) Modello matematico del fenomeno recente di evoluzione altimetrica dell'alveo dalla Becca a Pontelagoscuro. In: Tacconi P, Consorzio per il Canale Emiliano-Romagnolo (eds) Po: acquAgricolturAmbiente. Vol. 2. L'alveo e il delta. Il Mulino, Bologna, pp 163-273

Magistrato per il Po (1984) Per il Po e i suoi affluenti: 2o convegno di idraulica padana-Parma 1984. Edizioni Zara e Magistrato per il Po, Parma

Malfitano A (2011) Un territorio fragile: dibattito e intervento pubblico per l'Appennino tra Reno e Adriatico (1840-1970). Bononia University Press, Bologna

Marabini F (1985) Evoluzione della linea di riva del delta del Po. In: Atti della tavola rotonda tenuta a Bologna il 24 novembre 1982 su il Delta del Po: Sezione geologica. Tip. Compositori, Bologna, pp 71-99 
Marchetti M (2002) Environmental changes in the central Po Plain (northern Italy) due to fluvial modifications and anthropogenic activities. Geomorphology 44:361-373. https://doi.org/10.1016/S0169$555 \mathrm{X}(01) 00183-0$

Marzo Magno A, Iori T (2012) 150 anni di storia del cemento in Italia. Le opere, gli uomini, le imprese. Ediz. illustrata. Gangemi, Roma

Marzolo [Francesco], Istituto di Idraulica dell'Universita' di Padova (1957) Modello dell'impianto idroelettrico sul Fiume Po a Isola Serafina

Ministero dei Lavori Pubblici and Servizio Idrografico Centrale (1952) La piena del Po del novembre 1951. G Genio Civ 1:5-12

Mocarelli L (2010) Le piccole e medie imprese nel settore delle costruzioni: uno sguardo di lungo periodo. Quad Ric Sullartigianato 54:189-207

Morandini G (1958) Sul recente abbassamento del Delta Padano. Riv Geogr Ital LXV 62-65

Mosley S (2014) Environmental history of air pollution and protection. In: Agnoletti M, Neri Serneri S (eds) The basic environmental history. Springer International Publishing, Cham, pp 143-169

Ninfo A, Ciavola P, Billi P (2018) The Po Delta is restarting progradation: geomorphological evolution based on a 47-years Earth Observation dataset. Sci Rep 8:3457. https://doi.org/10.1038/ s41598-018-21928-3

Pandozy Prefetto di Rovigo (1960) Principali problemi del Polesine

Parrinello G (2017) Charting the flow: water science and state hydrography in the Po watershed, 18721917. Environ Hist 23:65-96. https://doi.org/10.3197/096734017X14809635325638

Parrinello G (2018) Systems of power: a spatial envirotechnical approach to water power and industrialization in the Po valley of Italy, ca.1880-1970. Technol Cult 59:652-688. https://doi.org/10.1353/tech. 2018.0062

Petts GE, Gurnell AM (2005) Dams and geomorphology: research progress and future directions. Geomorphology 71:27-47. https://doi.org/10.1016/j.geomorph.2004.02.015

Pritchard SB (2011) Confluence: the nature of technology and the the remaking of the Rhône. Harvard University Press, Cambridge, Mass, London

Rinaldi M, Surian N, Pellegrini L, et al (2010) Attuali conoscenze sull'evoluzione recente di corsi d'acqua del Bacino Padano ed implicazioni per la gestione e riqualificazione fluviale. Biol Ambient 24:29-40

Servizi Forestali della Regione Autonoma Valle d'Aosta (1964) Processo Verbale di contravvenzione a carico di B. Roberto

Sottocomitato tecnico (1957) Riunione del giorno 27 giugno 1957 presso gli uffici della SIMA

Stefani M (2017) The Po delta region: depositional evolution, climate change and human intervention through the Last 5000 Years. In: Soldati M, Marchetti M (eds) Landscapes and landforms of Italy. Springer, pp 193-202

Steffen W, Crutzen PJ, McNeill JR (2007) The anthropocene: are humans now overwhelming the great forces of nature. AMBIO J Hum Environ 36:614-621. https://doi.org/10.1579/0044-7447(2007) 36[614:TAAHNO]2.0.CO;2

Steffen W, Grinevald J, Crutzen P, McNeill J (2011) The Anthropocene: conceptual and historical perspectives. Philos Trans R Soc Lond Math Phys Eng Sci 369:842-867. https://doi.org/10.1098/rsta.2010. 0327

Stradling D, Stradling R (2008) Perceptions of the burning river: deindustrialization and Cleveland's Cuyahoga river. Environ Hist 13:515-535. https://doi.org/10.1093/envhis/13.3.515

Surian N, Rinaldi M (2003) Morphological response to river engineering and management in alluvial channels in Italy. Geomorphology 50:307-326. https://doi.org/10.1016/S0169-555X(02)00219-2

Surian N, Rinaldi M (2008) Dinamica recente ed attuale degli alvei fluviali in Italia: stato dell'arte e prospettive. Il Quat 21:233-240

Surian N, Ziliani L, Comiti F et al (2009) Channel adjustments and alteration of sediment fluxes in gravelbed rivers of North-Eastern Italy: potentials and limitations for channel recovery. River Res Appl 25:551-567. https://doi.org/10.1002/rra.1231

Syvitski JPM, Kettner AJ (2007) On the flux of water and sediment into the Northern Adriatic Sea. Cont Shelf Res 27:296-308. https://doi.org/10.1016/j.csr.2005.08.029

Syvitski JPM, Kettner A (2011) Sediment flux and the Anthropocene. Philos Trans R Soc Math Phys Eng Sci 369:957-975. https://doi.org/10.1098/rsta.2010.0329

Tchaprassian M (2002) L'impatto ambientale delle estrazioni di acque metanifere nel Polesine 1938-1964. In: Martuccelli AM (ed) La bonifica tra Canalbianco e Po. Vicende del Comprensorio Padano Polesano, Minelliana, Rovigo, pp 337-378

Visentini M (1939) Depositi alluvionali nei serbatoi italiani e trasporto solido fluviale. L'Elettrotecnica 16:743-752

Visentini M (1940) Ricerche idrografiche nel Delta del Po. Istituto Poligrafico dello Stato, Roma 
White R (1995) The organic machine: the remaking of the Columbia river. Hill and Wang, New York Winiwarter V, Schmid M, Dressel G (2013) Looking at half a millennium of co-existence: the Danube in Vienna as a socio-natural site. Water Hist 5:101-119. https://doi.org/10.1007/s12685-013-0079-x

Wohl E, Magilligan FJ, Rathburn SL (2017) Introduction to the special issue: connectivity in geomorphology. Geomorphology 277:1-5. https://doi.org/10.1016/j.geomorph.2016.11.005

Worster D (1985) Rivers of empire: water, aridity, and the growth of the American West. Pantheon Books, New York

(1904) Testo unico delle disposizioni di legge intorno alle opere idrauliche delle diverse categorie (1977a) “Inondazione colposa?" I magistrati apriranno probabilmente un'inchiesta. La Stampa 9 (1977b) Proibito scavare nel Toce. La Stampa

Publisher's Note Springer Nature remains neutral with regard to jurisdictional claims in published maps and institutional affiliations. 